\title{
Protein-Arginine Deiminase Type-2
}

National Cancer Institute

\section{Source}

National Cancer Institute. Protein-Arginine Deiminase Type-2. NCI Thesaurus. Code C132151.

Protein-arg inine deiminase type-2 (665 aa, $76 \mathrm{kDa}$ ) is encoded by the human PADI2 gene. This protein plays a role in the conversion of arginine residues to citrulline. 